\title{
Spatiotemporal changes in the genetic diversity of a bloom-forming Microcystis aeruginosa (cyanobacteria) population
}

\author{
Enora Briand ${ }^{1,2}$, Nicolas Escoffier ${ }^{3,4}$, Cécile Straub ${ }^{3}$, Marion Sabart ${ }^{3,5}$, Catherine Quiblier ${ }^{1,6}$ \\ and Jean-François Humbert ${ }^{3,4}$ \\ ${ }^{1}$ MNHN, USM505/EA4105 Ecosystèmes et interactions toxiques, Paris Cedex 05, France; ${ }^{2} S C E$, Département \\ Eau, Pôle Fleuves, Rivières et Milieux Humides, Route de Gachet, Nantes, France; ${ }^{3}$ Unité des Cyanobactéries, \\ Institut Pasteur-CNRS URA 2172, Paris, France; ${ }^{4} I N R A$, UMR CARRTEL, Thonon-les-Bains Cedex, France; \\ ${ }^{5}$ Laboratoire Microorganismes: génome et environnement, UMR CNRS 6023, Université Blaise Pascal, \\ Clermont-Ferrand II, Aubière Cedex, France and ${ }^{6}$ Université Paris Diderot, PRG, Paris, France
}

\begin{abstract}
The variations in microcystin concentrations during cyanobacterial blooms in freshwater ecosystems appear to depend on numerous factors, which have still not been fully identified. To contribute to clarify the situation, we have developed a spatial sampling approach to determine the dynamics and genetic diversity of a bloom-forming population of Microcystis aeruginosa in a large French reservoir, and the variations in the proportions of microcystin-producing genotypes. We demonstrated that marked changes occurred in the internal transcribed spacer (ITS) genotype composition of the $M$. aeruginosa population during the development of the bloom. These changes led progressively to the selection of one dominant ITS genotype throughout the entire reservoir when the cell number reached its maximum. At the same time, we identified a decrease in the proportion of the $m c y B+$ genotype, and a significant negative correlation between this proportion and that of the dominant ITS genotype during the bloom. Thus, it appeared that favorable conditions for Microcystis cell growth led to the selection, within the Microcystis population, of a nonmicrocystin-producing genotype, whereas potentially microcystin-producing genotypes were dominant in this population before and after the bloom, when environmental conditions were less favorable for growth.
\end{abstract}

The ISME Journal (2009) 3, 419-429; doi:10.1038/ismej.2008.121; published online 18 December 2008

Subject Category: microbial population and community ecology

Keywords: cyanobacteria; Microcystis aeruginosa; microcystins; bloom; genetic diversity

\section{Introduction}

Proliferations of harmful cyanobacteria are a growing problem in many freshwater ecosystems, and may be explained by the degradation of the water quality in many of them because of eutrophication (for example Carpenter et al., 1998; Smith et al., 1999) and, to a lesser extent, by climate warming (Paerl and Huisman, 2008; Shatwell et al., 2008; Jöhnk et al., 2008). In attempts to find out what governs cyanobacterial proliferations, over the past 10 years an increasing number of papers have dealt with the relative importance of biological, physicochemical and weather (for example Wiedner et al., 2002; Jacquet

Correspondence: J-F Humbert, Unité des Cyanobactéries, Institut Pasteur-CNRS URA 2172, 28 rue du Dr Roux, 75724 Paris Cedex 15, France.

E-mail: humbert@pasteur.fr

Received 28 October 2008; accepted 4 November 2008; published online 18 December 2008 et al., 2005; Catherine et al., 2008). Furthermore, several publications have recently investigated the genetic diversity of some bloom-forming cyanobacterial populations, to assess their population structure (for example Barker et al., 2000; Wilson et al., 2005; Tanabe et al., 2007) or to find out whether biogeographic differentiation occurs between these populations at different spatial scales (for example Bittencourt-Oliveira et al., 2001; Hayes et al., 2002; Laamanen et al., 2002; Gugger et al., 2005).

In most the studies of the population dynamics and genetics of cyanobacteria, only one sampling point per ecosystem are investigated, and this made it impossible to evaluate the spatial dynamics of the populations during the bloom development. As a result we do not know whether cyanobacterial blooms in large freshwater ecosystems start at a single point, and subsequently spread throughout the whole ecosystem, or whether blooms are initiated at several different places within the body 
of water. Similarly, there is no data available about the spatiotemporal pattern of genetic diversity during the development of cyanobacterial blooms, and this information could help to clarify the population dynamics, and to find out whether one or several genotypes are differentially selected at different places during bloom development. Knowing this would also allow us to estimate the spatial scale at which dominant genotypes are selected during the development of the proliferating populations.

It is also particularly interesting to compare the changes in the population dynamics and genetics during cyanobacterial proliferation to the change in cyanotoxin production. Many studies of microcystins (MCs), which are the most frequently detected cyanotoxins, have demonstrated that, for a given species, the potential toxicity of the proliferating populations varied greatly not only from place to place, but also over the time course of the blooms (for example Kardinaal and Visser, 2005; Rantala et al., 2006). These changes seem to be attributable mainly to changes in the relative proportions of potentially MC-producing and non-MC-producing genotypes in the population (for example Vaitomaa et al., 2003; Kurmayer et al., 2004) but also, to changes in the rate of MC production by the toxic genotypes (for example Sivonen, 1990; Kaebernick et al., 2000; Wiedner et al., 2003; Gobler et al., 2007). Moreover, the recent work of Briand et al. (2008a) demonstrated that during a Planktothrix agardhii proliferation there was an inverse correlation between the changes in the proportion of potentially toxic genotypes and in cyanobacterial cell abundances.

One interesting question about all these data is how to establish the links between the changes in cyanobacterial cell abundance, the genetic diversity of the population and the proportion of potentially MC-producing genotypes during the spatial course of the development of a bloom in an ecosystem. To provide some answers to these questions, we investigated the development of a Microcystis aeruginosa bloom in the Grangent reservoir, which is located on the Loire River in central France, using a sampling strategy based on surveying six points in the lake. Throughout the development of the bloom, the changes in the $M$. aeruginosa cell numbers and also in its genetic diversity was evaluated at each of these sampling points by sequencing the internal transcribed spacer (ITS) of the rRNA gene. We used the same samples to estimate the change in the proportion of potentially MC-producing and non-MC-producing genotypes using real-time PCR.

\section{Materials and methods}

Study area and sampling strategy

The Grangent reservoir $\left(45^{\circ} 27^{\prime} \mathrm{N} ; 4^{\circ} 15^{\prime} \mathrm{E}\right)$ is located in the Massif Central (France), near Saint-Etienne, in the upper part of the river Loire, and was created in 1957 (Figure 1). The reservoir has a surface area of

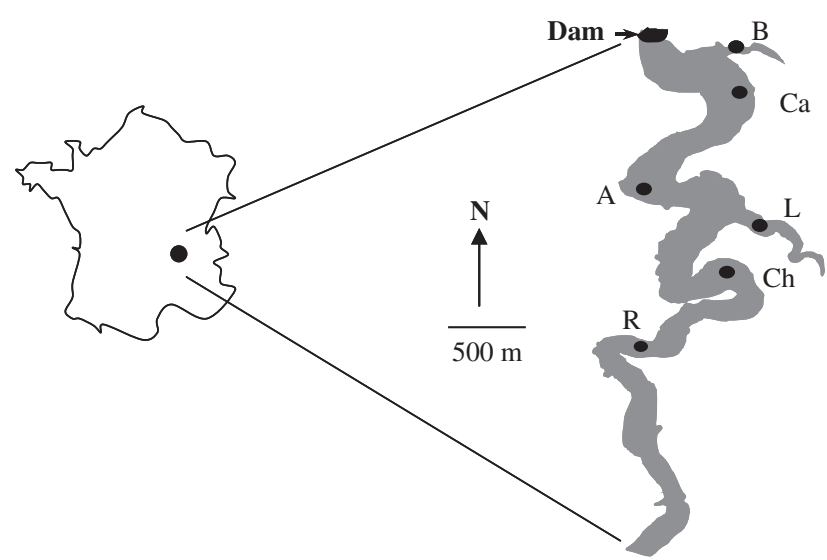

Figure 1 Location of the Grangent storage reservoir in France. Revotes (R), Chatelet (Ch), Lizeron (L), Anse (A), Camaldules (Ca) and Barrage (B) are the six sampling stations used in this study.

$365 \mathrm{Ha}$ with a length of $21 \mathrm{~km}$, a maximum depth of $50 \mathrm{~m}$ and a capacity of $57.4 \times 10^{6} \mathrm{~m}^{3}$. Lake Grangent constitutes an important water reservoir for energy production and irrigation. This water body is also a recreational area, used for bathing and nautical activities. Since 1970, external phosphorus loads have led to the hypereutrophication of the reservoir, which explains why $M$. aeruginosa blooms have been formed for several years (Berthon et al., 1996).

Sampling was conducted at six stations following an upstream/downstream gradient on the Grangent reservoir (Figure 1). The study sites were sampled every 2 weeks from 18 April to 1 August 2007. Water samples were collected $0.5 \mathrm{~m}$ below the surface using an electric pump that filtered 120, 60 or $30 \mathrm{l}$ of water (depending on the biomass) through a $20-\mu \mathrm{m}$ filter; and then concentrated the biomass over a 20$\mu \mathrm{m}$ filter into three 50-ml tubes (Greiner). The first sample, which was used for cyanobacterial counting, was preserved with Lugol's iodine (1:100) directly after sampling, and stored at $4{ }^{\circ} \mathrm{C}$. The two other samples were kept at $-20^{\circ} \mathrm{C}$ until tested for DNA extraction for molecular analysis (cloning, sequencing and real-time PCR).

M. aeruginosa cell densities (expressed in cells $\mathrm{l}^{-1}$ ) were determined in duplicate using a Malassez counting chamber with a Nikon Optiphot 2 microscope ( $\times 200$; Nikon, Melville, NY, USA) after the rapid disruption (20 s) of the colonial structure of $M$. aeruginosa by ultrasonication (ultrasonic processor at $25 \mathrm{kHz}$; Reynolds and Jaworski, 1978).

DNA extraction, PCR amplification and cloning-sequencing of the ITS

DNA was extracted according to the protocol of Humbert and Le Berre (2001) when cell number was sufficient to obtain good amplification of the ITS. Briefly, after filtering the sample, pieces of filter were placed in a tube and subjected to ultrasonication, as described previously, in $2-4 \mathrm{ml}$ cell lysis buffer $(0.05 \mathrm{M}$ Tris-HCl, $0.05 \mathrm{M} \mathrm{NaCl}, 0.05 \mathrm{M}$ EDTA at $\mathrm{pH}$ 8, and with 
a final concentration of $10 \mathrm{mg} \mathrm{ml}^{-1}$ of lysozyme). The tubes were incubated at $37^{\circ} \mathrm{C}$ for $1 \mathrm{~h}$. Proteinase $\mathrm{K}$ $\left(0.5 \mathrm{mg} \mathrm{ml}^{-1}\right)$ and $1 \%$ sodium dodecyl sulfate were then added, and the tubes were placed in a water bath at $40{ }^{\circ} \mathrm{C}$ and left overnight. After a phenol-chloroform extraction, and ethanol precipitation, the DNA extracted was stored at $-40^{\circ} \mathrm{C}$ until used.

The ITS sequence of the rRNA operon was amplified in each DNA extract. The 50- $\mu$ l PCR mixtures contained 10-100 ng of template DNA, a $100-\mu \mathrm{M}$ concentration of each of the four deoxyribonucleotide triphosphates, $5 \times$ PCR reaction buffer, a $200 \mu \mathrm{M}$ concentration of $\mathrm{MgCl}_{2}, 0.4 \mu \mathrm{M}$ of each primer (forward primer: 5'-TGTAAAACGACGGCCA GTCCATGGAAG(CT)TGGTCA(CT)G-3'; reverse primer: 5'-CCTCTGTGTGCCTAGGTATCC-3'; Iteman et al., 2005) and $1 \mathrm{U}$ of Taq DNA Polymerase (GoTaq Flexi DNA Polymerase; Promega, Madison, WI, USA). The DNA template and a negative control were subjected to an initial denaturing step at $95{ }^{\circ} \mathrm{C}$ for $10 \mathrm{~min}$. The following 35 cycles consisted of a $30 \mathrm{~s}$ denaturing step at $95^{\circ} \mathrm{C}$, a $30 \mathrm{~s}$ annealing step at $60{ }^{\circ} \mathrm{C}$ and a $60 \mathrm{~s}$ extension step at $72^{\circ} \mathrm{C}$. A final $7 \mathrm{~min}$ extension step was carried out at $72{ }^{\circ} \mathrm{C}$. Amplifications of the target region were checked by electrophoresis on a $1.5 \%$ agarose gel stained with ethidium bromide. In every sample, a single band was observed by electrophoresis, which is consistent with the fact that the ITS sequence is the same in the two rRNA operons present in Microcystis (Janse et al., 2003; Humbert et al., 2005).

Positive PCR products were purified before cloning using the QIAquick PCR Purification Kit (Qiagen, Hilden, Germany) according to the protocol provided with the kit. Purified PCR products were cloned in pGEM-T vector system II (Promega) according to the manufacturer's instructions (1:12:1 molar ratio of the PCR products to the vectors). Between 40 and 50 white colonies were randomly picked from each clone library for the sequencing, which was performed by GATC Biotech using commercial SP6 (5'-TAGGTGACACTATAGAATAC$\left.3^{\prime}\right)$ primer. For further analyses, we used only the sequences sharing $>95 \%$ identity with the $M$. aeruginosa, Microcystis viridis, Microcystis wesenbergii, Microcystis ichthyoblabe and Microcystis novacekii sequences from GenBank. DNA-DNA hybridization experiments (Otsuka et al., 2001) suggest that all these species are conspecific. All nucleotide sequences have been deposited in the GenBank-EMBL database under the accession numbers EU867825-EU868608.

The sequences were aligned using ClustalW in Mega4 software (Tamura et al., 2007), and manually corrected in GeneDoc (Nicholas and Nicholas, 1997). A minimum spanning tree, which connects all genotypes together with the lowest total cost was constructed using BioNumerics software (Applied Maths) using the default setting. Estimations of nucleotide diversity, analyses of molecular variance (AMOVA), and pairwise $F_{\mathrm{ST}}$ calculations were performed using Arlequin software v3.0 (Excoffier et al., 2005). The AMOVA approach makes it possible to study the genetic structure of populations in an analysis of variance framework taking into account the number of mutations between genotypes. We compared three groups of populations, which were defined on the basis of the sampling dates (24 May, 8 June and 22 June).

Finally, a Multidimensional scaling (MDS) analysis of the genotypic composition of each sample was performed using XLStat software (Addinsoft). This analysis represents the similarities between all the sampling points at each sampling date in a twodimensional graph.

\section{Multiplex real-time PCR}

The proportion of mcy genotypes in the Microcystis population was determined by a real-time PCR analysis. Two target gene regions were used: the intergenic spacer region within the phycocyanin $(P C)$ operon and the $m c y B$ region, which carries out one step in MC biosynthesis (Tillett et al., 2000), and was located between core motifs A2 and A3 (Marahiel et al., 1997). The primers and probes used for the $P C$ and $m c y B$ genes (listed in Table 1), which are specific for Microcystis, are those described previously by Kurmayer and Kutzenberger (2003). Fluorescent reporter and quencher dyes for probe of $P C$ gene were modified (from 5 -FAM and $3^{\prime}$-TAMRA to $5^{\prime}$-CYA and $3^{\prime}$-BHQ-2) to perform mutiplex real-time PCR and to discriminate between the two amplifications in a same run.

Amplification by real-time PCR was carried out using an Mx3005P thermal cycler (Stratagene, Amsterdam, the Netherlands). All the reactions were performed with $20-\mu \mathrm{l}$ volumes in 96-well plates (Stratagene). The multiplex reaction mix contained $10 \mu \mathrm{l}$ of $2 \times$ QuantiTec Probe PCR kit mix (Qiagen), a 300-nM (300 fmol $\mu^{-1}$ ) concentration of each primer, a 100-nM concentration of the TaqMan probe for $P C$ gene amplification and a

Table 1 Real-time PCR primers and probes used in this study

\begin{tabular}{ll}
\hline $\begin{array}{l}\text { Gene region } \\
\text { and primers } \\
\text { or probes }\end{array}$ & Sequence $^{\mathrm{a}}\left(5^{\prime}-3^{\prime}\right)$ \\
\hline $\begin{array}{l}\text { mcyB region: } \\
\text { 30F }\end{array}$ & CCTACCGAGCGCTTGGG \\
108R & GAAAATCCCCTAAAGATTCCTGAGT \\
Probe & FAM-CACCAAAGAAACACCCGAATCTGAGA \\
& GG-TAMRA \\
PC gene region: & \\
$188 \mathrm{~F}$ & GCTACTTCGACCGCGCC \\
$254 \mathrm{R}$ & TCCTACGGTTTAATTGAGACTAGCC \\
Probe & CYA-CCGCTGCTGTCGCCTAGTCCCTG- \\
& BHQ-2
\end{tabular}

Abbreviation: $P C$, phycocyanin.

aFAM, 6-carboxyfluorescein; TAMRA, 6-carboxytetramethylrhodamine; CYA, 5-indocarboxycyanine; BHQ-2, black hole quencher-2. 
900-nM concentration of each primer, a 250-nM concentration of the TaqMan probe for $m c y B$ and $2 \mu \mathrm{l}$ of template containing various amounts of genomic DNA. The mix was then filled to $20 \mu \mathrm{l}$ with sterile Millipore water. Each sample was prepared in triplicate. Negative controls without DNA were included for each PCR run. The temperature cycle consisted of an initial preheating step of $15 \mathrm{~min}$ at $95{ }^{\circ} \mathrm{C}$, followed by 40 cycles of $30 \mathrm{~s}$ at $95^{\circ} \mathrm{C}$ (denaturing), $1 \mathrm{~min}$ at $60^{\circ} \mathrm{C}$ (annealing) and $30 \mathrm{~s}$ at $72{ }^{\circ} \mathrm{C}$ (extension). For data analysis, the threshold for the fluorescence of all the samples was set manually to 132 (relative fluorescence) for $P C$ gene amplification, and to 665 for mcyB amplification to obtain the best PCR efficiency using linear-log calibration curves. The sizes of the amplicons were 66- and 78-bp for the $P C$ and $m c y B$ genes, respectively.

We used a novel method, the change in threshold cycle $\left(\Delta C_{\mathrm{T}}\right.$; Briand et al., 2008a), to estimate the relative proportion of the the Microcystis population by a single multiplex real-time PCR. We had tested the reproducibility of the method beforehand by applying it to several MC-producing Microcystis strains. Standard curves for the $P C$ and $m c y B$ genes were constructed using the genomic DNA of eight MC-producing Microcystis strains PCC 7806, 7813, PCC 7820, PCC 7941, PCC 9354, PCC 9355, PCC 9443 and PCC 9808. For each strain, serial dilutions containing $1.1 \times 10^{1}$, 1.1 , $1.1 \times 10^{-1}, \quad 1.1 \times 10^{-2}, \quad 1.1 \times 10^{-3}, \quad 1.1 \times 10^{-4}$ and $1.1 \times 10^{-5} \mathrm{ng}$ of the genomic DNA $\mu \mathrm{l}^{-1}$ were prepared. The standard curves were established by relating the known quantity of DNA (in pg) to the threshold cycle $\left(C_{\mathrm{T}}\right)$ number (the cycle number at which the fluorescence exceeds the threshold) for each diluted sample (Table 2 and Figure 2a). For both genes, highly significant linear plots of the amounts of genomic DNA of the Microcystis strains versus the $C_{\mathrm{T}}$ numbers were obtained. The regression equations, and the resulting $\Delta C_{\mathrm{T}}$ between the two genes $\left(\Delta C_{\mathrm{T}}=C_{\mathrm{T}}\right.$ for the $P C$ gene $-C_{\mathrm{T}}$ for $\left.\operatorname{mcy} B\right)$ are shown in Table 2. We found that there was a narrow range of $\Delta C_{\mathrm{T}}$ values (with a mean $\Delta C_{\mathrm{T}}$ value of $-2.14 \pm 0.36$ ) for all eight MC-producing Microcystis strains. As the $C_{\mathrm{T}}$ decreases by 1 when the quantity of DNA decreases by $50 \%$, the following equation was deduced from the $\Delta C_{\mathrm{T}}$ values theoretically calculated for proportions of $m с y B$ genotype strains of $100 \%, 50 \%, 25 \%$ and $12.5 \%$ of the population: $y=3.32 \times \log (x)-8.78$, where $y$ is the $\Delta C_{\mathrm{T}}$, and $x$ is the initial percentage of the mсyB genotype strains.

This theoretical $\Delta C_{\mathrm{T}}$ equation was experimentally validated with samples containing a mix of the MCproducing strain PCC 7806, and the non-MC-producing strain PCC 9806. Five samples containing $12.5 \%, 25 \%, 50 \%, 75 \%$ and $100 \%$ of the MCproducing strain, respectively, were tested, and the $\Delta C_{\mathrm{T}}$ for each percentage was calculated (Figure 2b1). The resulting $\Delta C_{\mathrm{T}}$ equation $(y=3.27 \times \log (x)-8.53$; Figure 2b2) was similar to the theoretical $\Delta C_{\mathrm{T}}$ equation $(y=3.32 \times \log (x)-8.78)$, which validates our approach.

For each run of samples, serial dilutions containing $1.1 \times 10^{1}, 1.1,1.1 \times 10^{-1}, 1.1 \times 10^{-2}, 1.1 \times 10^{-3}$, $1.1 \times 10^{-4}$ and $1.1 \times 10^{-5} \mathrm{ng}$ of the genomic DNA $\mu \mathrm{l}^{-1}$ were prepared from the DNA extract of an MCproducing $M$. aeruginosa strain to serve as external standards for the real-time PCR. The $\Delta C_{\mathrm{T}}$ method was applied at each time point (Briand et al., 2008a), and an equation was deduced from the $\Delta C_{\mathrm{T}}$ values theoretically calculated for proportions of MCproducing strain corresponding to $100 \%, 50 \%$, $25 \%$ and $12.5 \%$ of the population: $y=a \log (x)-b$, where $y$ is the $\Delta C_{\mathrm{T}}$ and $\mathrm{x}$ is the initial percentage of MC-producing strain.

Table 2 Regression equations for the $P C$ and mcyB genes and values of $\Delta C_{\mathrm{T}}$

\begin{tabular}{lll}
\hline Microcystis strain & Regression equation for the PC gene & Regression equation for the mcyB gene \\
\hline PCC 7806 & $y=-3.09 \times \log (x)+29.25$ & \\
& $\left(R^{2}=0.99 ; n=3 ; P<10^{-3}\right)$ & $y=-3.35 \times \log (x)+32.02$ \\
PCC 7813 & $y=-3.03 \times \log (x)+28.83$ & $\left(R^{2}=0.99 ; n=3 ; P<10^{-3}\right)$ \\
& $\left(R^{2}=0.99 ; n=4 ; P<10^{-4}\right)$ & $y=-3.09 \times \log (x)+30.97$ \\
PCC 7820 & $y=-2.91 \times \log (x)+27.31$ & $\left(R^{2}=0.99 ; n=4 ; P<10^{-4}\right)$ \\
& $\left(R^{2}=0.99 ; n=5 ; P<10^{-4}\right)$ & $y=-2.96 \times \log (x)+29.30$ \\
PCC 7941 & $y=-3.06 \times \log (x)+28.82$ & $\left(R^{2}=0.99 ; n=5 ; P<10^{-4}\right)$ \\
& $\left(R^{2}=0.99 ; n=3 ; P<10^{-3}\right)$ & $y=-3.17 \times \log (x)+30.66$ \\
PCC 9354 & $y=-2.98 \times \log (x)+28.37$ & $\left(R^{2}=0.99 ; n=3 ; P<10^{-3}\right)$ \\
& $\left(R^{2}=0.99 ; n=3 ; P<10^{-3}\right)$ & $y=-3.13 \times \log (x)+30.64$ \\
PCC 9355 & $y=-2.84 \times \log (x)+27.82$ & $\left(R^{2}=0.99 ; n=3 ; P<10^{-3}\right)$ \\
& $\left(R^{2}=0.99 ; n=4 ; P<10^{-4}\right)$ & $y=-2.90 \times \log (x)+29.85$ \\
PCC 9443 & $y=-3.02 \times \log (x)+28.82$ & $\left(R^{2}=0.99 ; n=4 ; P<10^{-4}\right)$ \\
PCC 9808 & $\left(R^{2}=0.99 ; n=3 ; P<10^{-3}\right)$ & $y=-3.00 \times \log (x)+30.42$ \\
& $y=-2.61 \times \log (x)+29.03$ & $\left(R^{2}=0.99 ; n=3 ; P<10^{-3}\right)$ \\
& $\left(R^{2}=0.97 ; n=3 ; P<10^{-3}\right)$ & $y=-2.73 \times \log (x)+31.49$ \\
& & $\left(R^{2}=0.97 ; n=3 ; P<10^{-3}\right)$ \\
& & $M e a n \Delta C_{\mathrm{T}}$
\end{tabular}

Abbreviation: $P C$, phycocyanin.

The regression equations were based on predetermined DNA concentrations of MC-producing Microcystis strains, where $y$ is the $C_{\mathrm{T}}$ value and $x$ is the starting concentrations of DNA (in pg). 

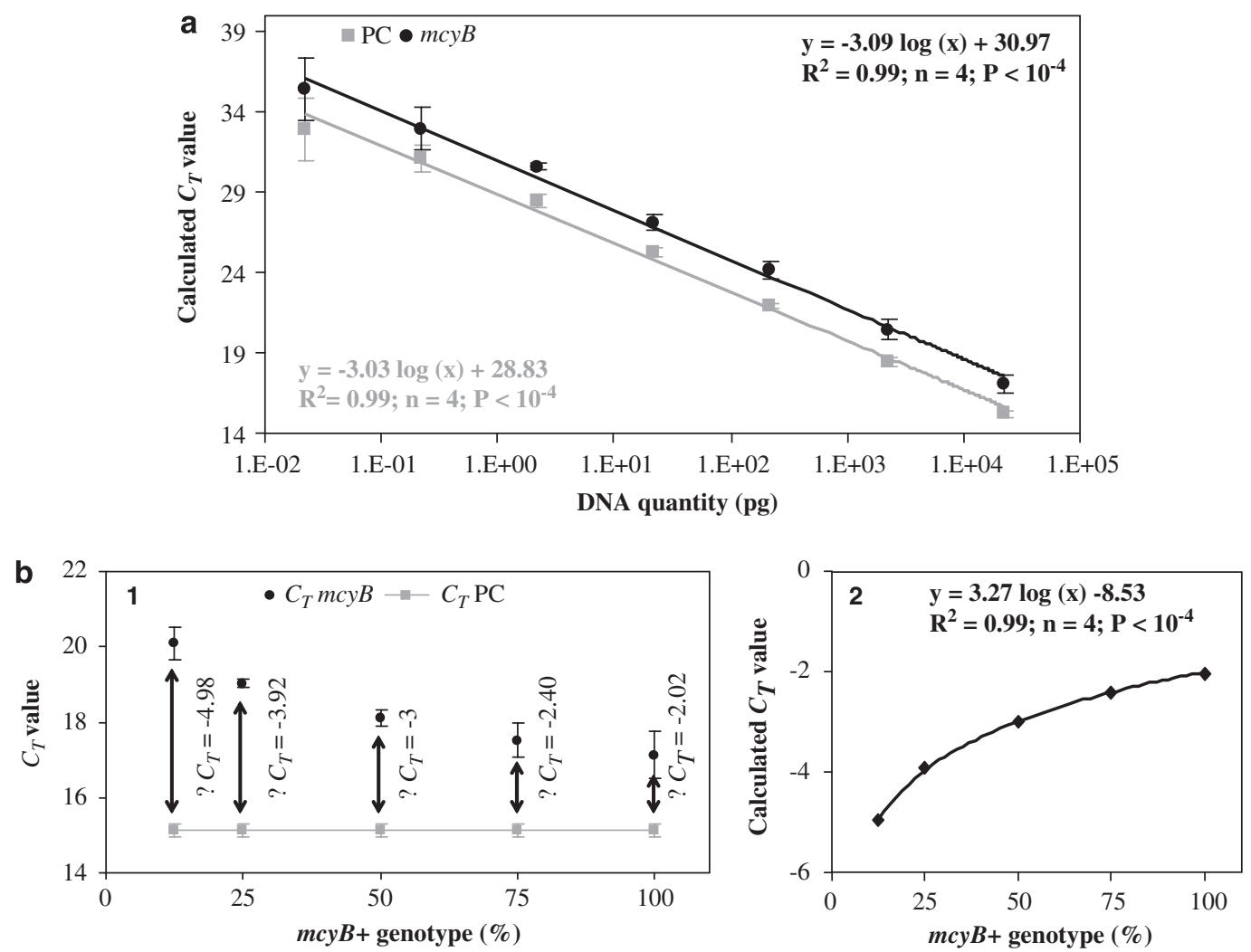

Figure 2 (a) Example of the standard curves for the mcyB (black circles) and phycocyanin (PC; gray squares) genes based on predetermined concentrations of DNA of the microcystin (MC)-producing Microcystis strain PCC 7813 amplified by multiplex real-time PCR. (b1) Example of $C_{\mathrm{T}}$ numbers obtained for the mcyB (black circles) and $P C$ (gray squares) genes amplified by multiplex real-time PCR from a mix of MC-producing (PCC 7806), and non-MC-producing (PCC 9806) Microcystis strains. (b2) The $\Delta C_{\mathrm{T}}$ was calculated for each mix, and the $\Delta C_{\mathrm{T}}$ equation was obtained by relating the calculated $\Delta C_{\mathrm{T}}$ to the percentage of cells with mcyB genotype. The error bars indicate standard deviations $(n=4)$.
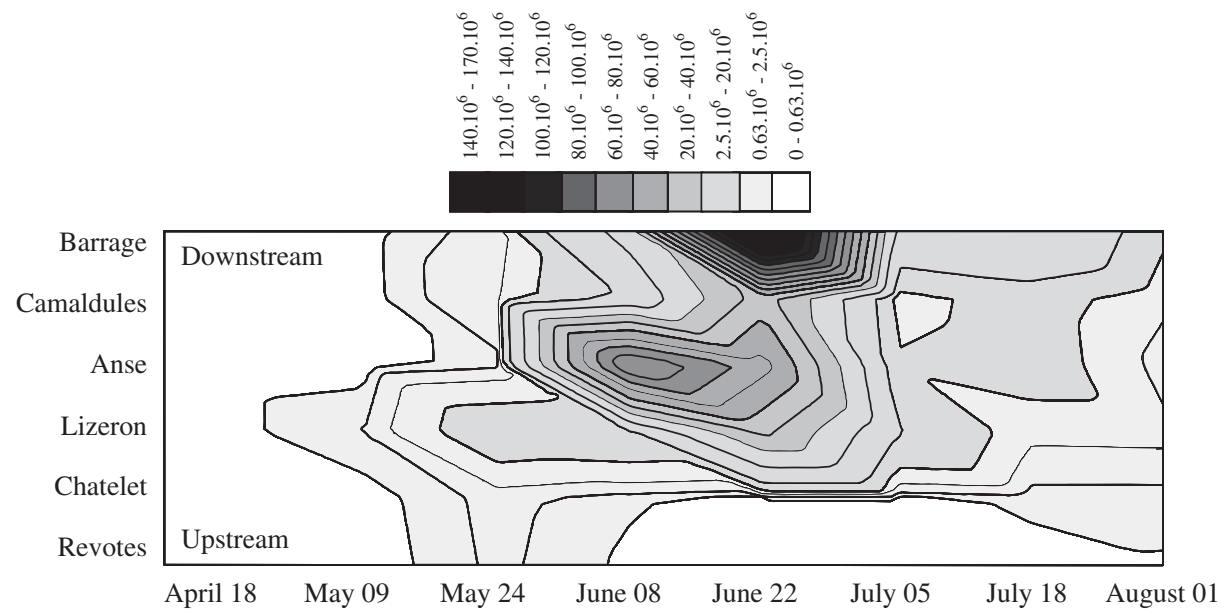

Figure 3 Spatiotemporal changes in the Microcystis cell density (number of cells $\mathrm{l}^{-1}$ ) in the Grangent reservoir.

\section{Results}

Variations in the abundance of $\mathrm{M}$. aeruginosa in the Grangent reservoir

Throughout the survey, the sites located in the upstream part of the Grangent reservoir (for example
Revotes and Chatelet) were always characterized by low M. aeruginosa cell densities $\left(<1.6 \times 10^{6}\right.$ cells $\left.^{-1}\right)$, and most of the highest Microcystis cell numbers occurred in the middle and downstream parts of the reservoir (Figure 3). The M. aeruginosa bloom began to develop in early May at the Lizeron sampling 
point, which is located in the middle part of the Grangent reservoir (there was a rise from $7.4 \times 10^{3}$ cells $1^{-1}$ on 18 April to $1.3 \times 10^{6}$ cells $\mathrm{l}^{-1}$ on 9 May). By the end of May, the Microcystis cell densities were very similar at all the sampling points. The first cell abundance peak $\left(9.2 \times 10^{7}\right.$ cells $\left.\mathrm{l}^{-1}\right)$ was found on 8th June, at the Anse sampling point, and a second peak 15 days later at the Barrage sampling point, which is located not far from the dam (cell density: $18 \times 10^{7}$ cells $\mathrm{l}^{-1}$ ). Two weeks later ( 5 July), the bloom had declined throughout the reservoir, and cell abundances remained at a very low level for the rest of the summer.

Changes in the proportions of the mcyB + and $\mathrm{mcyB}-$ genotypes during the $\mathrm{M}$. aeruginosa bloom The changes in the relative proportions of the $m c y B+$ and $m c y B-$ genotypes during the $M$. aeruginosa bloom were estimated using a multiplex real-time PCR of the $m c y B$ and $P C$ genes (Figure 4). We found that the proportions of mcyB + genotypes varied considerably over time, and between different sites (ranging from 6\% to 93\% in the $M$. aeruginosa population). However, it appeared that at the scale of the entire reservoir the highest proportions of $m c y B+$ genotypes were found at the beginning of the bloom (from $60 \%$ to $93 \%$ of the whole M. aeruginosa population), and also 4 weeks after the decline of the bloom, in August (Figure 4). On the other hand, the lowest proportions of $m c y B+$ genotypes were found at the height of the $M$. aeruginosa bloom, and just after the decline of the bloom (a fall of between $6 \%$ and $58 \%$ in the M. aeruginosa population; Figure 4).

Looking at each sampling site in more detail, it also emerged that there were some differences in the dynamics of the proportions of $m c y B+$ genotypes at the different sampling points. For example, at the Camaldules station, there was an initial increase in the proportions of $m c y B+$ genotypes followed by a very marked decrease at the peak of the bloom. On

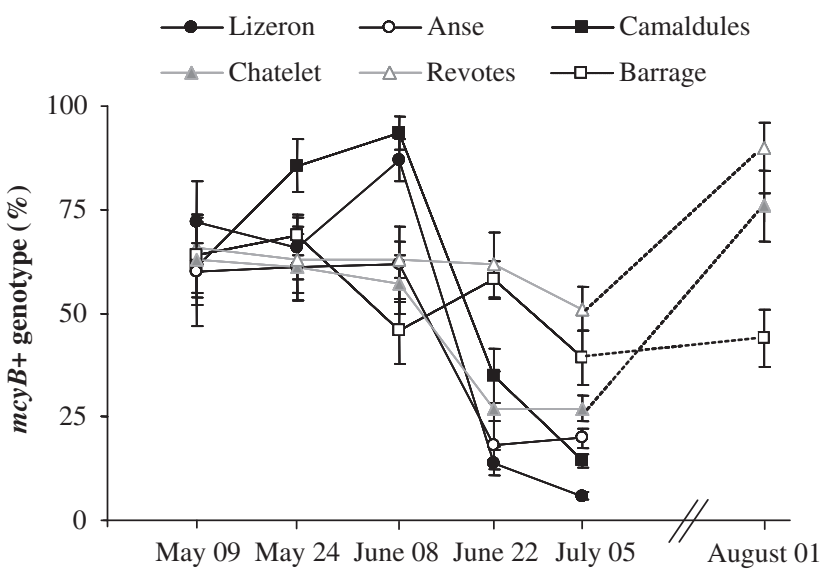

Figure 4 Changing proportions over time of mcyB + genotypes in the Grangent Microcystis population at the different sampling points. The error bars indicate standard deviation $(n=3)$. the other hand, the proportion of $m c y B+$ genotypes at the Revotes sampling station did not display any major change at any time during the study.

Changes in the genotype composition of the $\mathrm{M}$. aeruginosa population based on the sequencing of the ITS of the rRNA operon

In all, 784 ITS sequences were obtained during be sequencing, and 306 different genotypes were identified, in which each genotype differed by at least one mutation from all other genotypes. Twentyseven of these genotypes were found in at least two different samples, and three (C1, C2 and C3) of these 27 genotypes were found in almost all the samples, and contained a total of 411 sequences. The minimum spanning tree approach (Figure 5) highlighted the presence of three main groups of genotypes, which were separated by high genetic distances. Moreover, it appeared that the three dominant genotypes (C1, C2 and C3) were located in the center of these three main groups, implying that the numerous genotypes located at the periphery were only distinguished from the three main genotypes by a very restricted number of mutations. Using a neighbor-joining approach (data not shown), we found that the three dominant genotypes, and the rare genotypes associated with each of them, constituted three very distinct groups.

The changing nature of the genotype composition of the Microcystis population during the development of the bloom was characterized by marked changes in the proportions of these three dominant genotypes (Figure 6). Before the bloom (24 May), the C1 and C2 genotypes dominated the Microcystis population at all sampling points, and there was no difference between the five sampling sites, as revealed by the $F_{\mathrm{ST}} P$-values, which were not significantly different from $0 \quad(=$ no significant difference in the genotypic composition of each sample; Supplementary Table S1). At the time of the peak Microcystis biomass (22 June), apart from the Chatelet sampling point, where the C1 and C2 genotypes were present in roughly the same proportions as C3, there was no genetic difference between

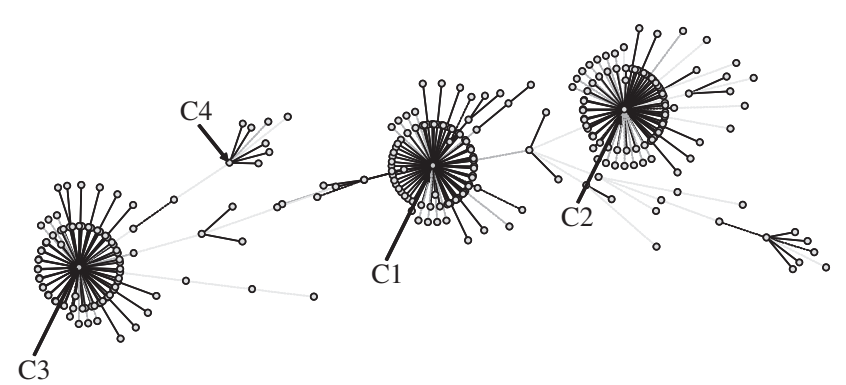

Figure 5 Minimum spanning tree obtained from the 784 internal transcribed spacer sequences of Microcystis. Distance coding between genotypes: thick line: distance $\leqslant 1$; thin line: distance $\leqslant 2$; dash line, density 1 : distance $\leqslant 3$, density 2 : distance $\leqslant 4$, density 3 : distance $\leqslant$ other. 


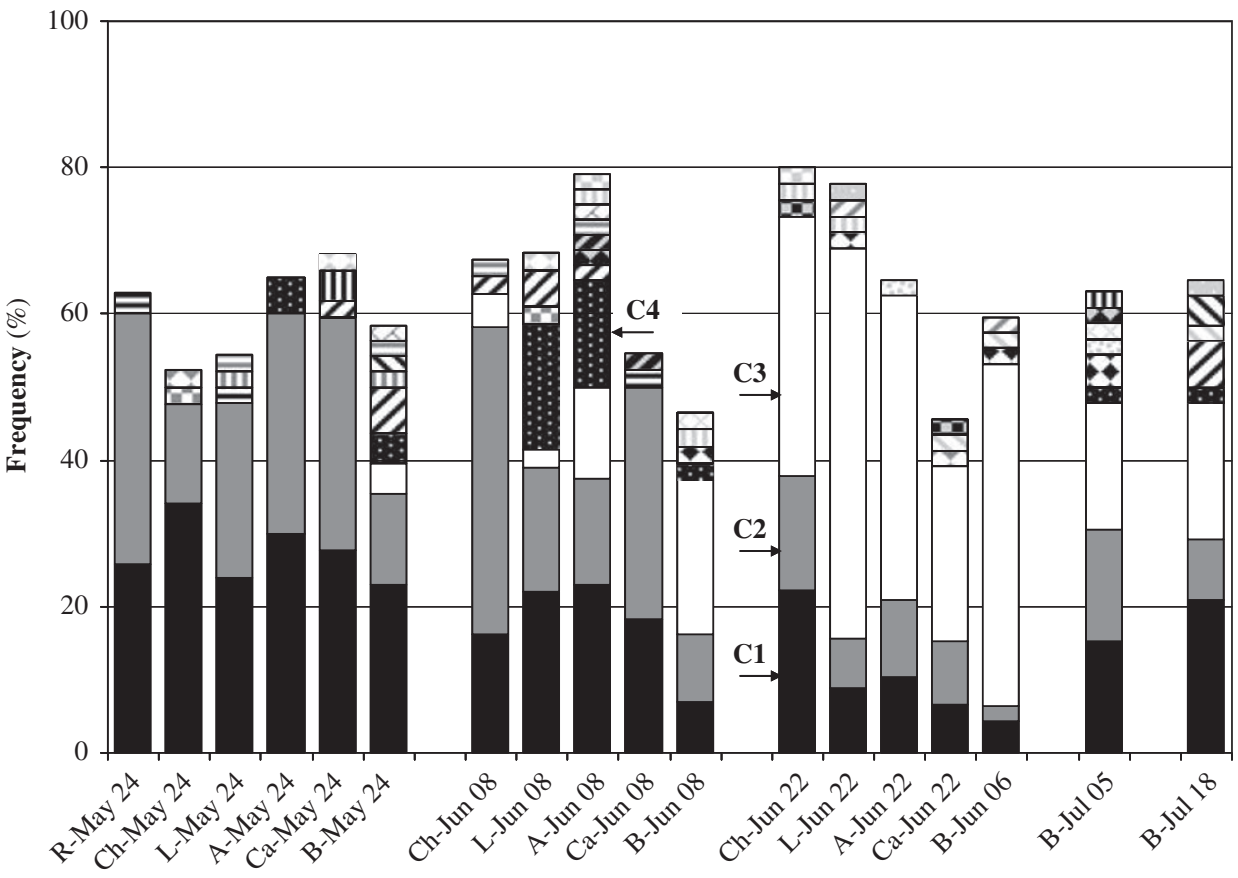

Figure 6 Changes in the rRNA internal transcribed spacer (ITS) genotypic composition of the Microcystis population at different sampling points of the Grangent reservoir. R: Revotes; Ch: Chatelet; L: Lizeron; A: Anse; Ca: Camaldules; B: Barrage.

the other four sampling points, which were all characterized by the dominance of the C3 genotype $\left(F_{\mathrm{ST}} P\right.$-values not significantly different from 0$)$. Between these two times (8 June), when there had been an initial increase of cyanobacterial abundance at the Anse sampling point, the genotype composition of the Microcystis population was characterized by marked spatial differences, as shown by the $F_{\text {ST }}$ $P$-values, most of which were significantly different from 0 . At this time, four main genotypes (C1, C2, C3 and C4) were found in very variable proportions at the different sampling points. Finally, significant genetic differentiation $(P<0.01)$ was detected by AMOVA analysis when the three groups of population defined on the basis of the sampling date (24 May, 8 June and 22 June) were taken into account. After the bloom, the proportions of the C3 genotype declined sharply at the Grangent sampling point.

An MDS analysis performed on the distribution of the 27 genotypes identified in at least two samples, provided an overall picture of the similarities and differences between the different sampling points on the basis of their genotype composition. As shown in Figure 7, the dispersal of the results for the different sampling points was much greater on 8 June than it had been before the first increase in Microcystis cell abundance was seen (24 May), and also than at the subsequent peak cell abundance (22 June). This analysis showed that the Barrage sampling station differed most from the others before the bloom. On the other hand, during the bloom, it was the Chatelet sampling point, which is located in the upstream part of the reservoir that stood out most from the other four sampling points.

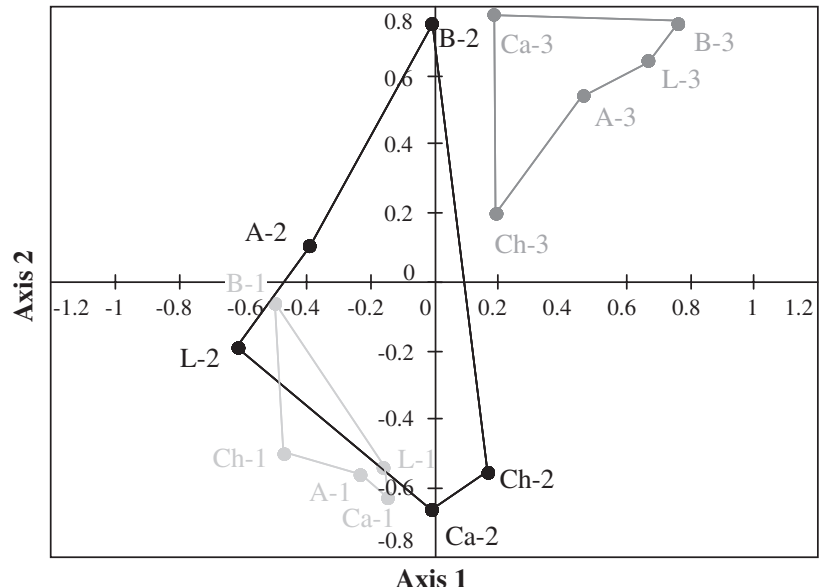

Figure 7 Multidimensional scaling analysis of the distribution of the different internal transcribed spacer (ITS) genotypes at the different sampling points during the development of the Microcystis bloom (stress Kruskal =0.068). R: Revotes; Ch: Chatelet; L: Lizeron; A: Anse; Ca: Camaldules; B: Barrage; 1: 24 May; 2: 8 June; 3: 22 June.

Finally, we also found that there was a significant negative correlation $\left(R^{2}=0.64 ; \quad n=15 ; \quad P<10^{-3}\right)$ between changes in the proportions of the C3 genotype, and of the mcyB + genotypes in the Microcystis population (Figure 8).

\section{Discussion}

This study is, to the best of our knowledge, the first to describe both the spatial aspects of the 


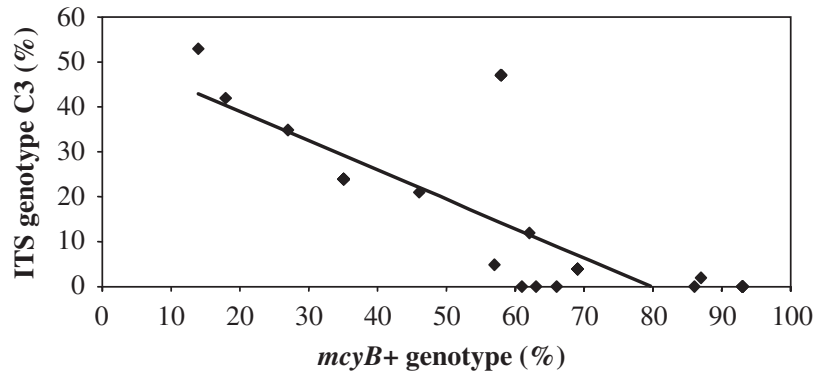

Figure 8 Relationship between the changes in the proportions of microcystin-producing genotypes (mcyB + genotypes) and the changes in the proportion of the internal transcribed spacer (ITS) C3 genotype in the Microcystis population in the Grangent reservoir.

development of a bloom-forming $M$. aeruginosa population in a large freshwater ecosystem, and the simultaneous changes that occur in the genotype composition of this population and in the proportions of potentially MC-producing $m c y B+$ genotypes. The main questions we set out to answer were whether some specific genotypes were selected during bloom development and, if so, whether this selection was linked to changes in the potential toxicity of the cyanobacterial population, and finally, whether these phenomena occurred at the scale of the whole reservoir or only in restricted areas.

During this study, the Microcystis cell numbers in the Grangent reservoir were characterized initially by a sharp increase in Microcystis cell abundance from May 2007 to the end of June, and then by a sharp decrease in these cell densities. This unexpected decrease during the summer can be explained by the unusual weather recorded in this region in July 2007, with cold temperatures and high rainfall for the season (data not shown). With different environmental conditions in July, much greater cell densities would probably have been obtained, as observed in this reservoir in 2005 for example (Latour-Duris, personal communication). Despite this, this survey provided us with an opportunity to estimate how a Microcystis bloom grows and moves at the scale of an entire ecosystem. Our findings identified marked spatial variations during the development of the bloom, which was characterized by higher cell abundances in the middle and downstream parts of the reservoir. As in other studies (for example Hotto et al., 2007; Moreno-Ostos et al., 2008), this heterogeneous spatial distribution of Microcystis biomass might have been generated by greater cyanobacterial growth in areas where conditions for growth were better, or by displacement of the population by currents or winds, leading to an accumulation of a high cyanobacterial biomass in some areas. Some findings from the ITS genotyping suggested that both these processes were probably involved in the heterogeneous distribution of Microcystis biomass in the Grangent reservoir. For example, the fact that at the peak of the bloom the dominant genotype (C3) was first selected in the downstream part of the reservoir, suggests that this area was very important for the development of the bloom. However, a clear demonstration of the relative importance of these two processes would require more intensive sampling in space and in time.

These findings highlight, the fact that, as already pointed out by Chorus and Fastner (2001), multipoint sampling provides a better estimate and better understanding of the population dynamics of cyanobacteria in freshwater ecosystems, both in monitoring surveys and basic research. This could be very important, for instance, in studies trying to link changes in cyanobacterial biomass to changes in potential toxicity, and may account for some of the contradictory findings reported in the literature on this topic (see for example the review of Kardinaal and Visser, 2005).

It is interesting to compare our findings regarding the changes in the ITS genotype composition of the Microcystis population during the bloom with the data available about the genetic diversity of other cyanobacterial species. Indeed, we found that three clearly phylogenetically distinct genotypes (C1, C2 and C3) dominated the Microcystis population, but also that there were many other rare genotypes closely related to these three dominant genotypes, as revealed by the minimum spanning tree. It is probable that some of these rare genotypes were generated by PCR or sequencing bias, but some others could also reflect the existence of major microdiversity within the Microcystis population. Such microdiversity has previously been identified in another cyanobacterial genus, Prochlorococcus (Fuhrman and Campbell, 1998; Moore et al., 1998), and associated with different ecotypes that allow Prochlorococcus to occupy a wide range of environmental conditions. As Microcystis is distributed worldwide, we could expect this genus also to contain different ecotypes that are able to grow under very diverse environmental conditions. Finally, this finding is also interesting in the light of data available about the genome of this genus. Two Microcystis strains have recently been sequenced (Kaneko et al., 2007; Frangeul et al., 2008), and Frangeul et al. (2008) have shown that the genome of this genus seems to be highly plastic, allowing to Microcystis to promote diversification.

Concerning the relationships between the changes occurring in the ITS genotype composition, and those in the proportions of potentially MC-producing and non-MC-producing genotypes, it appeared that replacement of the two initially dominant ITS genotypes (C1 and $\mathrm{C} 2$ ) in the population by a third genotype (C3) was concomitant with a decrease in the proportions of $m c y B+$ genotypes, and also with the increase in Microcystis cell abundance. Moreover, the negative correlation between changes in the proportions of the C3 genotype, and in the $m c y B+$ genotypes in the Microcystis population 
suggests that the ITS C1 and C2 genotypes, which were dominant before the bloom, were possibly $m c y B+$ genotypes. These findings also suggest that, under environmental conditions favorable for cyanobacterial growth, the ITS C3 genotype displayed greater fitness than the other ITS genotypes, and that this C3 genotype may have been a mcyB-genotype. This association between the ITS genotypes and their potential ability to produce MCs is consistent with the paper of Janse et al. (2004), which demonstrated a close link between the ITS genotype of several Microcystis colonies and their ability to produce MCs. Some differences were found between the different sampling sites in the evolution of the proportions of mcyB + genotypes in the Microcystis population. We are not able to provide any good explanation for these differences, but we think that it is more interesting to take into account the overall change in proportions, to minimize all the sources of bias (from sampling to real-time PCR) that could have influenced the estimation of these values.

The fact that favorable environmental conditions for Microcystis growth seems to lead to the selection of non-toxic genotypes is consistent with field survey data showing a negative relationship between the cyanobacterial biomass and the average MC cell content during the development of cyanobacterial blooms (for example Kardinaal and Visser, 2005), and also with the recent paper of Briand et al. (2008a) demonstrating a negative correlation between the cell abundance and the proportion of potentially MC-producing genotypes during a $P$. agardhii bloom. Moreover, two experimental studies have recently demonstrated for $M$. aeruginosa (Kardinaal et al., 2007) and P. agardhii (Briand et al., 2008b), respectively, that under environmental conditions favorable for cyanobacterial growth, the fitness of non-MC-producing strains was greater than that of MC-producing ones.

In this paper we did not set out to investigate what happens after the bloom in the Microcystis population, but our data do shed some light on this. The first finding is that after the decrease in Microcystis abundance (July 2007), the proportions of toxic genotypes initially remained unchanged, before increasing to reach the same level as before the bloom there also appeared to be a concomitant decrease in the proportion of the ITS C3 genotype, and an increase in that of the C1 and C2 genotypes, which is consistent with the increase in the proportions of $m c y B+$ genotypes after the bloom. These initial findings seem to indicate that the mortality of Microcystis cells was higher among cells with the C3 genotype than among those with the C1 and C2 genotypes. This confirms that under unfavorable conditions for cyanobacterial growth, potentially MC-producing genotypes may have greater fitness than non-MC-producing ones, as previously reported for $P$. agardhii (Briand et al., 2008a, b).
To conclude, in addition to providing some answers to our initial questions concerning the spatial development of a bloom in a large reservoir, and the changes occurring in the genotypic composition during the course of the bloom, this study also provides new evidence that MC-producing and non-MC-producing cyanobacterial cells may display different fitness depending on the environmental conditions. The high proportions of MCproducing genotypes found before and after the bloom, when conditions for growth were not optimal, and conversely, their decrease during the bloom, when environmental conditions favored cyanobacterial growth, suggest that the benefits of producing MCs are particularly great under environmental conditions that limit cell growth. However, it also suggests that the cost of the MC production outweighs its benefits when environmental conditions promote good cyanobacterial growth.

\section{Acknowledgements}

We would like to thank Pierre Sauvignet for technical assistance in sampling. Monika Ghosh is acknowledged for improving the English version of the article. This work was supported by two ANR research programs (PRECODD: project Proliphyc; SEST: project Matrics).

\section{References}

Barker GLA, Konopka A, Handley BA, Hayes PK. (2000). Genetic variation in Aphanizomenon (cyanobacteria) colonies from the Baltic Sea and North America. J Phycol 36: 947-950.

Berthon JL, Devaux J, Aleya L, Giraudet H, Restituito F. (1996). Déterminisme de l'eutrophisation de la retenue de Grangent (Loire): étude des apports en nutriments, de la dynamique des populations phytoplanctoniques et des relations phyto-zooplancton en 1990-1991. Hydroécol Appl 8: 99-125.

Bittencourt-Oliveira MC, Cabral de Oliveira M, Bolch CJS. (2001). Genetic variability of Brazilian strains of the Microcystis aeruginosa complex (cyanobacteria/ cyanophyceae) using the phycocyanin intergenic spacer and flanking regions ( $c p c \mathrm{BA})$. J Phycol 37: 810-818.

Briand E, Gugger M, François JC, Bernard C, Humbert JF, Quiblier C. (2008a). Temporal variations in the dynamics of potentially microcystin-producing strains in a bloom-forming Planktothrix agardhii (cyanobacteria) population. Appl Environ Microbiol 74: 3839-3848.

Briand E, Yéprémian C, Humbert JF, Quiblier C. (2008b). Competition between microcystin- and non-microcystin-producing Planktothrix agardhii (cyanobacteria) strains under different environmental conditions. Environ Microbiol 10: 3337-3348.

Catherine A, Quiblier C, Yéprémian C, Got P, Groleau A, Vinçon-Leite B et al. (2008). Collapse of a Planktothrix agardhii perennial bloom and microcystin dynamics in response to reduced phosphate concentrations in a temperate lake. FEMS Microbiol Ecol 65: 61-73. 
Carpenter SR, Caraco NF, Correll DL, Howarth RW, Sharpley AN, Smith VH. (1998). Nonpoint pollution of surface waters with phosphorus and nitrogen. Ecol Appl 3: 559-568.

Chorus I, Fastner J. (2001). Recreational exposures to cyanotoxins. In: Chorus I (ed). Cyanotoxins: Occurrence, Causes, Consequences. Springer: Berlin, Germany. pp 190-199.

Excoffier L, Laval G, Schneider S. (2005). Arlequin ver. 3.0: an integrated software package for population genetics data analysis. Evol Bioinfo Online 1: 7-50.

Frangeul L, Quillardet P, Castets AM, Humbert JF, Matthijs HCP, Cortez D et al. (2008). Highly plastic genome of Microcystis aeruginosa PCC 7806, a ubiquitous toxic freshwater cyanobacterium. BMC Genomics 9: 274.

Fuhrman JA, Campbell L. (1998). Microbial microdiversity. Nature 393: 410-411.

Gobler CJ, Davis TW, Coyne KJ, Boyer GL. (2007). Interactive influences of nutrient loading, zooplankton grazing, and microcystin synthetase gene expression on cyanobacterial bloom dynamics in a eutrophic New York lake. Harmful Algae 6: 119-133.

Gugger M, Molica R, Le Berre B, Dufour P, Bernard C, Humbert JF. (2005). Genetic diversity of Cylindrospermopsis strains (cyanobacteria) isolated from four continents. Appl Environ Microbiol 71: 1097-1100.

Hayes PK, Barker GLA, Batley J, Beard SJ, Handley BA, Vacharapiyasophon P et al. (2002). Genetic diversity within populations of cyanobacteria assessed by analysis of single filaments. Antonie Van Leeuwenhoek 81: 197-202.

Hotto AM, Satchwell MF, Boyer GL. (2007). Molecular characterization of potential microcystin-producing cyanobacteria in lake Ontario embayments and nearshore waters. Appl Environ Microbiol 73: 4570-4578.

Humbert JF, Duris-Latour D, Le Berre B, Giraudet H, Salençon MJ. (2005). Genetic diversity in Microcystis populations of a French storage reservoir assessed by sequencing of the 16S-23S rRNA Intergenic Spacer. Microb Ecol 49: 308-314.

Humbert JF, Le Berre B. (2001). Genetic diversity in two species of freshwater cyanobacteria, Planktothrix (Oscillatoria) rubescens and P. agardhii. Arch Hydrobiol 150: 197-206.

Iteman I, Rippka R, Tandeau de Marsac N, Herdman M. (2005). Comparison of conserved structural and regulatory domains within divergent $16 \mathrm{~S}$ rRNA-23S rRNA spacer sequences of cyanobacteria. Microbiology 146: $1275-1286$

Jacquet S, Briand JF, Leboulanger C, Avois-Jacquet C, Oberhaus L, Tassin B et al. (2005). The proliferation of the toxic cyanobacterium Planktothrix rubescens following restoration of the largest natural French lake (Lac du Bourget). Harmful Algae 4: 651-672.

Janse I, Kardinaal WEA, Meima M, Fastner J, Visser PM, Zwart G. (2004). Toxic and nontoxic Microcystis colonies in natural populations can be differentiated on the basis of $r R N A$ gene internal transcribed spacer diversity. Appl Environ Microbiol 70: 3979-3987.

Janse I, Meima M, Kardinaal WEA, Zwart G. (2003). High resolution differentiation of cyanobacteria by using rRNA-internal transcribed spacer denaturing gradient gel electrophoresis. Appl Environ Microbiol 69: 6634-6643.

Jöhnk KD, Huisman J, Sharples J, Sommeijer B, Visser PM, Stroom JM. (2008). Summer heatwaves promote blooms of harmful cyanobacteria. Glob Change Biol 14: 495-512.

Kaebernick M, Neilan BA, Börner T, Dittmann E. (2000). Light and the transcriptional response of the microcystin biosynthesis gene cluster. Appl Environ Microbiol 66: 3387-3392.

Kaneko T, Narajima N, Okamoto S, Suzuki I, Tanabe Y, Tamaoki $\mathrm{M}$ et al. (2007). Complete genomic structure of the bloom-forming toxic cyanobacterium Microcystis aeruginosa NIES-843. DNA Res 14: 247-256.

Kardinaal WEA, Tonk L, Janse I, Hol S, Slot P, Huisman J et al. (2007). Competition for light between toxic and nontoxic strains of the harmful cyanobacterium Microcystis. Appl Environ Microbiol 73: 2939-2946.

Kardinaal WEA, Visser PM. (2005). Dynamics of cyanobacterial toxins: sources of variability in microcystin concentrations. In: Huisman J, Matthijs HCP, Visser PM (eds). Harmful Cyanobacteria. Springer: Berlin, Germany. pp 41-63.

Kurmayer R, Christiansen G, Fastner J, Börner T. (2004). Abundance of active and inactive microcystin genotypes in populations of toxic cyanobacterium Planktothrix spp. Environ Microbiol 6: 831-841.

Kurmayer R, Kutzenberger T. (2003). Application of real-time PCR for quantification of microcystin genotypes in a population of the toxic cyanobacterium Microcystis sp. Appl Environ Microbiol 69: 6723-6730.

Laamanen MJ, Forsström L, Sivonen K. (2002). Diversity of Aphanizomenon flos-aquae (cyanobacterium) populations along a Baltic Sea salinity gradient. Appl Environ Microbiol 68: 5296-5303.

Marahiel MA, Stachelhaus T, Moetz HD. (1997). Modular peptide synthetases involved in nonribosomal peptide synthesis. Chem Rev 97: 2651-2673.

Moore LR, Rocap G, Chisholm SW. (1998). Physiology and molecular phylogeny of coexisting Prochlorococcus ecotypes. Nature 393: 464-467.

Moreno-Ostos E, Cruz-Pizzaro L, Basanta A, George DG. (2008). The spatial distribution of different phytoplankton functional groups in a Mediterranean reservoir. Aquat Ecol 42: 115-128.

Nicholas KB, Nicholas HB. (1997). Genedoc: a tool for editing and annotating multiple sequence alignments. Distributed by the author (www.nrbsc.org/gfx/genedoc/index.html).

Otsuka S, Suda S, Shibata S, Oyaizu H, Matsumoto S, Watanabe MM. (2001). A proposal for the unification of five species of the cyanobacterial genus Microcystis Kützing ex Lemmermann 1907 under the rules of the bacteriological code. Int J Syst Evol Microbiol 51: 873-879.

Paerl HW, Huisman J. (2008). Blooms like it hot. Science 320: $57-58$

Rantala A, Rajaniemi-Wacklin P, Lyra C, Lepistö L, Rintala J, Mankiewicz-Boczek J et al. (2006). Detection of microcystin-producing cyanobacteria in Finnish lakes with genus-specific microcystin synthetase gene $\mathrm{E}$ (mcyE) PCR and associations with environmental factors. Appl Environ Microbiol 72: 6101-6110.

Reynolds CS, Jaworski GHM. (1978). Enumeration of natural Microcystis populations. $\mathrm{Br}$ Phycol $J$ 13: 269-277.

Shatwell T, Köhler J, Nicklisch A. (2008). Warming promotes cold-adapted phytoplankton in temperate lakes and opens a loophole for Oscillatoriales in spring. Glob Change Biol 14: 1-7. 
Sivonen K. (1990). Effect of light, temperature, nitrate, orthophosphate, and bacteria on growth of and hepatotoxin production by Oscillatoria agardhii strains. Appl Environ Microbiol 56: 2658-2666.

Smith TH, Tilman GD, Nekola JC. (1999). Eutrophication: impacts of excess nutrient inputs on freshwater, marine, and terrestrial ecosystems. Environ Pollut 1-3: 179-196.

Tamura K, Dudley J, Nei M, Kumar S. (2007). MEGA4: molecular evolutionary genetics analysis (MEGA) software version 4.0. Mol Biol Evol 24: 15961599.

Tanabe Y, Kasai F, Watanabe MM. (2007). Multilocus sequence typing (MLST) reveals high genetic diversity and clonal population structure of the toxic cyanobacterium Microcystis aeruginosa. Microbiol 153: 3695-3703.

Tillett D, Dittmann E, Erhard M, von Döhren H, Börner T, Neilan BA. (2000). Structural organization of microcystin biosynthesis in Microcystis aeruginosa
PCC7806: an integrated peptide-polyketide synthetase system. Chem Biol 7: 753-764.

Vaitomaa J, Rantala A, Halinen K, Rouhiainen L, Tallberg P, Mokelke L et al. (2003). Quantitative real-time PCR for determinationof microcystin synthetase E copy numbers for Microcystis and Anabaenain lakes. Appl Environ Microbiol 69: 7289-7297.

Wiedner C, Nixdorf B, Heinz R, Wirsing B, Neumann U, Weckesser J. (2002). Regulation of cyanobacteria and microcystin dynamics in polymictic shallow lakes. Arch Hydrobiol 155: 383-400.

Wiedner C, Visser PM, Fastner J, Metcalf JS, Codd GA, Mur LR. (2003). Effects of light on the microcystin content of Microcystis strainPCC 7806. Appl Environ Microbiol 69: 1475-1481.

Wilson AE, Sarnelle O, Neilan BA, Salmon TP, Gehringer MM, Hay ME. (2005). Genetic variation of the bloomforming cyanobacterium Microcystis aeruginosa within and among lakes: implications for harmful algal blooms. Appl Environ Microbiol 71: 6126-6133.

Supplementary Information accompanies the paper on The ISME Journal website (http://www.nature.com/ismej) 